The

Carl Beck

Papers

in Russian \&

East European Studies

James W. Peterson

Number 2102

\title{
European Security, East and West: The Significance of the Missile Shield Proposal
}

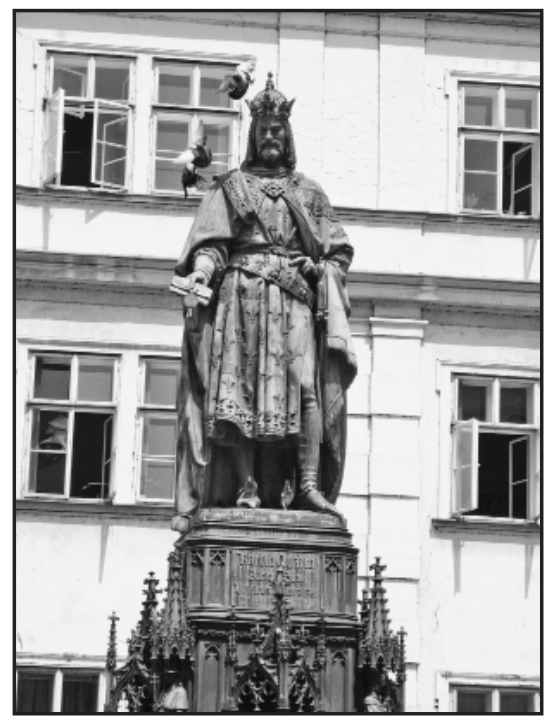


The

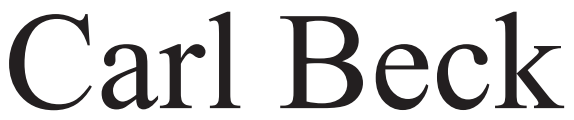

Papers

in Russian \&

East European Studies

Number 2102

James W. Peterson

European Security,

East and West:

The Significance of the

Missile Shield Proposal 
Dr. James W. Peterson is Professor and Head of the Department of Political Science at Valdosta State University in Valdosta, Georgia. He received his B.A. in Government from Cornell University. He also has an M.A. in Government and a Ph.D. in Political Science from Indiana University. He is the author of NATO and Terrorism: Organizational Expansion and Mission Transformation. New York: The Continuum International Publishing Group, 2011. Recent publications include "The Party Isn't Over: An Analysis of the Communist Party in the Czech Republic," with Jiří Lach, James LaPlant, and David Hill, 2010, The Journal of Communist Studies and Transition Politics, 26 (3): 363-388; "The Czech Republic and the World: Conflicting Loyalties, Organizational Memberships, and Changed National Images," Carl Beck Papers in Russian and East European Studies, No. 1907, August, 2008; and "An Expanded NATO Confronts Terrorism and Instability,” 2007, The Journal of Slavic Military Studies 20(04): 475-497.

No. 2102, June 2011

(C) 2011 by The Center for Russian and East European Studies, a program of the University Center for International Studies, University of Pittsburgh

ISSN 0889-275X

Image from cover: Statue of Charles IV at the foot of the Charles Bridge in Prague. Thanks to Bonnie Peterson for the image.

The Carl Beck Papers

Editors: William Chase, Bob Donnorummo, Ronald H. Linden

Managing Editor: Eileen O’Malley

Editorial Assistant: Julie N. Tvaruzek

Submissions to The Carl Beck Papers are welcome. Manuscripts must be in English, double-spaced throughout, and between 40 and 90 pages in length, including notes. Acceptance is based on anonymous review. Mail submissions to: Editor, The Carl Beck Papers, Center for Russian and East European Studies, 4400 Wesley W. Posvar Hall, 230 South Bouquet Street, University of Pittsburgh, Pittsburgh, PA 15260. 


\begin{abstract}
The Missile Shield Proposal, with the intended emplacement both of its radar site in the Czech Republic and of its anti-missile interceptors in Poland, emerged from the Bush Administration in the United States, a NATO partner to the West, and was directed at threats emanating from the East. As such, it became for a time a meeting place between American and Czech security goals. A range of political pressures eventually came to bear upon the proposal. External political pressures included Russian anxiety about the real target of the missile shield itself, while internal pressures entailed serious political party and public concerns in the Czech Republic. In spite of those pressures, the executive leadership in both countries approved the plan in mid-2008. However, following the American elections later in 2008, President Obama cancelled the project in the first year of his administration. At the same time, his attention to the urgency of European security led him to endorse a substitute proposal that would offer a similar level of security. Thus, the senior NATO partner to the West continued to maintain a priority on protection of the Czech Republic and other European neighbors against dangers in the East.
\end{abstract}


The regional security of Europe on both its eastern and western flanks was as fragile as American national defense after the events of September 11, 2001. Toward the east, European leaders and peoples worried about the links and meetings that al Qaeda operatives had established through European cities in preparation for the attacks. Their vulnerability even existed in the areas of conflict. For example, the Czech Republic had experienced both military casualties in Afghanistan and the death of their ambassador to Pakistan (iDNES 2008 s,t). Toward the west, Europeans concerned themselves with potential terrorist efforts to launch future attacks on the United States from nests well hidden on European territory.

Coupled with such apprehensions were emerging concerns about new nuclear powers in the east. The ostensible reason for America's creation of the "coalition of the willing" in the 2003 invasion of Iraq was its fear of that country's nuclear weapon's program. The failure to locate any evidence of that such a program did not allay security concerns on the nuclear issue, for Iran became a country of concern shortly thereafter. There was a parallelism between the negotiations among key western powers with Iran's leaders and the deliberations that entangled the United Nations and Iraqi leadership just prior to the 2003 war.

In the public mind as well as within the perceptions of European leaders, the continued al Qaeda activities and plans of al Qaeda comingled with the nuclear feints and threats emanating from Iraqi and Iranian spokespersons. There were differences and boundaries between those two sets of dangers, but several circumstances made the distinctions less clean. Iraq after 2003 served as a magnet that attracted and drew in remnants of al Qaeda and related groups that no longer found Afghanistan hospitable ground. These groups fed on and exacerbated the festering wounds that afflicted Iraq throughout most of the decade. Further, Iran openly mobilized its oil wealth to assist the terrorist groups that moved so smoothly and secretly across state borders. As a result, the Bush administration developed the missile shield proposal as a contribution by the United States, and potentially NATO, to an enhanced security situation for all of Europe. The United States as a western partner would finance and construct a barrier of sorts that could underpin European security in the face of imminent dangers from the east.

\section{The Missile Shield Proposal}

What exactly was this proposal that preoccupied the American, Czech, and Polish governments in 2007-09? Much of the focus of this essay will be on the Czech component, but most of the conclusions apply to the overall project and thus 
incorporate the Polish features as well. In what sense did this western proposal have the potential to guarantee the defense of Europe against threats that powers to its east presented? Basically, the missile shield would have extended protection across an arc of countries from much of the eastern Atlantic Ocean to the western part of the Pacific Ocean. The new protection would have covered much of western Africa and nearly all of Europe. Both the western and eastern parts of Russia would as well have come under the umbrella. However, the arc of protection would only have stretched north through western Russia to the Arctic Circle, and then it would have bent down into eastern Siberia. The vast middle of Russia would not have been covered; nor would Central/South Asia or the Gulf states (Ministry of Foreign Affairs of the Czech Republic 2009). Partial coverage of Russia enabled the advocates of the shield to argue that the program did not really threaten or aim at Russia. Overall, the protection afforded by the project would have dealt mainly with threats from either Iran or North Korea.

While ten antimissile interceptors would have been based in Poland, the accompanying radar detection site would have been in the Czech Republic in Brdo, southeast of Prague. Ideally, the Czech-based radar would detect incoming ballistic missiles in time for the Polish-based interceptors to shoot them down. Presumably, the capability would extend to both the middle and later stages of a missile attack against one of the protected partners. The whole system would have become part of the existing protective umbrella that bore the title of American Ground-Based Midcourse Defense.

Critics of the system raised technical concerns that have impacted the political debate. Some criticisms paralleled the Cold War debate over the feasibility of creating any dependable missile defense system. For example, Garwin $(2008,41)$ argues that radar systems could not distinguish between dangerous warheads and aluminum covered balloons, if all were painted the same color. This factor forces those who manage the defense system to deploy far more interceptors than the number of incoming missiles. Lewis and Postol $(2008,38)$ point out that the enemy could complicate matters further by enclosing the missile itself in a balloon that mimics all the other decoys. Concerns also arose about the ability of the components of the missile shield to pick up accurately the exact number of incoming warheads. It would be one thing for the radar to detect one incoming missile. However, it would be a far greater challenge for the defense system to develop strong enough infrared sensors that could distinguish an incoming warhead from other objects. The enemy could also create a dense "cloud of targets" with small wires less than 
two centimeters long. The resulting "chaff" would make it impossible to decide if reflections emanated from the warhead itself or from a piece of wire.

Such technical considerations merged with political and strategic issues to make the debate over the missile shield complex and challenging to the national security leadership in the Czech Republic, Poland, and the United States. Some of the above-noted criticisms played a role in the decision of the Obama Administration to cancel the proposed program in fall 2009. However, it is important to understand the mix of considerations that led to all the work on this proposal for enhancing the security of Europe on both its western and eastern flanks.

\section{American Security Goals in Central Europe}

The security goals of the United States in Central Europe since the end of the Cold War have centered on several key objectives. In part, the goal has been to nurture the growth of capitalist economies in the former countries of the communist bloc with an eye to developing strong partnerships with countries in the West. Stimulation of the democratic process has been an additional target in light of the four decades of autocratic control. Both these initial processes offered the promise of a more dependable integration into the West. In addition, stability has been a principal value whose importance the chaotic Balkan Wars of the 1990s underlined. A further goal throughout the period has been expansion of NATO to include these postcommunist nations into a cohesive military alliance. Finally, creation of a buffer against post-9/11 terrorism has been a pressing and urgent need early in the twenty-first century. Taken as a whole, this set of five American security goals sets the table for examination of two hypotheses. First, the decision to advocate creation of the missile shield took place as a result of post-Cold War American objectives that included economic, political, and security concerns. Second, substantial questions about Czech autonomy emerged in a visible way as that nation, its leaders, and people became caught up in the web of American goals.

In the early years after the 1989 revolutions in Central Europe, American policy supported the conversion to capitalist economies. In part, this meant the fostering of connections between western economic organizations and their counterparts in Central and Eastern Europe. For example, the Czechs entered into a cooperative arrangement with French companies to rebuild their main airport in Prague. Injection of western financial resources and know-how was directed at restarting the economies that had labored under communist-controlled central planning and quotas for so many decades. In part, the policy of the United States was to encourage the 
move to free-market capitalism within a reasonable period of time. For Romania, this meant a prolonged process that stretched into the late 1990s (Gledhill and King 2008, 326-27). For the Hungarians it meant a moderately paced transition, while for the Poles it entailed "shock therapy" for several years (Argentieri 2008, 225-27). American policy also supported the exchange of economic specialists. Central European economists came to western universities to learn the most advanced techniques, while American and Western European academics traveled to Central Europe to share their expertise. In these ways, American policy more or less engaged with the economic transition in the region in the belief that an economic base might underpin a sense of security in the region where as a vacuum would invite trouble.

Stoking the fires of democracy has been another security-related goal of American policy in the region. One reason for promoting democracy is simply that it has been a NATO entry requirement. NATO and eventually the European Union (EU) required establishment of democratic procedures prior to entry. The logic of such a requirement is the necessity of extending a long-standing security alliance on the basis of common values. In addition, the idea of the "democratic peace" received much attention in the 1990s. Countries that established functioning democracies seemed safer and less prone to provocation of their neighbors and continuing tensions with one another (Jentleson 2007, 519-25). In contrast, those countries that hung on to autocratic forms were considered more likely to lash out militarily against border countries. Variations in the region were apparent. On the one hand, the Baltic states quickly enacted democratic reforms after 1991. All three simply restored the constitutions that had governed them in the 1920s and 1930s, prior to their absorption into the Soviet Union in 1940 (Eglitis 2008, 241). Estonia, Latvia, and Lithuania also had higher levels of economic development than most of the other former Soviet republics. Further, Lithuania had been one of the leaders in the break-up of the Soviet Union. After establishing functioning democracies, all three were, by the end of the decade, vigorously involved in meeting the criteria for both EU and NATO admission, and they entered both regional organizations in 2004. On the other hand, several of the Yugoslav successor states were reluctant to abandon communist-era autocratic political patterns, and thus their fate was quite different. Serbia loomed as a NATO enemy in the Bosnian War and the Kosovo crisis, while Croatia produced a nationalist leadership whose features for some years bore striking resemblance to those of its communist predecessors (Baskin and Pickering 2008, 295-98). Overall, under American leadership, the West integrated new democracies into its security structures more quickly than it did regimes that clung to authoritarian patterns. 
Promotion of a stable region is implicit in the previously mentioned American objectives, but that goal is also a separate part of a larger historical tapestry. After World War I, Central Europe became a political and security vacuum. Collapse of the old empires resulted in creation of fledgling democracies, most of which gave way to more authoritarian variants within a decade (Wolchik and Curry 2008, 10-11). Those centralized regimes were a disappointment to publics that had welcomed the new democratic dawn in 1918. The global and regional economic collapse of the late 1920s and early 1930s compounded the sense of collective misery. Soon powerful nationalist movements emerged in a number of countries in the region. Native fascist organizations such as the Arrow Cross in Hungary and Iron Guard in Romania served as harbingers of the immediate future. Nazi ambitions capitalized on the emerging vacuum of accountability, and Hitler's forces moved in to dominate the region for the duration of World War II. This pattern of vulnerability repeated itself in the postwar period when the Soviet Union exploited the military weakness and the lack of effective political governance in the region. In such a highly volatile and unstable atmosphere, the region fell under communist influence for a full four decades (Hesli 2007, 49, 245).

It certainly seemed apparent that the post-1989 situation was a less dangerous one for the region. However, the rise of rogue leadership in the Balkans and nearby Middle East made the risk of another political and security vacuum further to the north too great. While Central Europe was no longer the primary theater that it had been during the Cold War, its strategic location required priority treatment.

The American plan for emplacement of a radar station in the Czech Republic fitted into this priority of increased stability. President George W. Bush visited Prague in June 2007, while Secretary of Defense Robert Gates followed up with a visit in October. Both emphasized the importance of this facility in strengthening regional security against threats further to the east (iDNES 2007j). NATO Secretary-General Jaap de Hoop Scheffer underlined the regional security theme on a visit to Romania in the fall of 2007. He stated that the principle of security was indivisible and that the missile shield capability should protect equally each NATO partner (iDNES 2007n). Even if Iran stopped its work on a nuclear program, security against conventional weapons would also be advanced by the radar system (iDNES 2007o). By the end of 2007, arguments by Czech Minister of Foreign Affairs Karel Schwarzenberg on behalf of the radar shield emphasized its ability to protect both Western and Central Europe (iDNES, 2007s). His American counterpart Condoleezza Rice expanded the application of the shield to the entire Euroatlantic region (iDNES 20081). Thus, 
the Czech component of the missile shield was an important device for furthering the security of Central Europe as well as its eastern neighbors.

Expansion of NATO to include many of the postcommunist nations would buttress regional security in important ways. The Clinton administration, through its Partnership for Peace program, offered observer status to qualified postcommunist states by the middle of the 1990s. In the immediate aftermath of the first Persian Gulf War, and at the time of the tragic Bosnian War, a widened military alliance made a great deal of sense. By 1999, just months before the NATO bombing campaign in Kosovo, NATO deemed three nations ready for full membership: the Czech Republic, Hungary, and Poland. After more years of negotiation, in 2004 NATO admitted Bulgaria, Estonia, Latvia, Lithuania, Romania, Slovakia, and Slovenia. With ten Central European nations within the alliance, a potential vacuum was filled and security broadened. Particularly difficult was the decision to bring in the three Baltic nations. As they became part of this western military alliance, their potential to provoke Russian reactions was very real (Michta 2006, 18). The presence of Russian minorities in the Baltic region was a factor in those reactions, as Russia expressed both protectiveness and defensiveness toward them. However, Russian reactions to the admission of all ten new members softened somewhat over time. Instead of opposing NATO expansion per se, Russian President Vladimir Putin became more selective and reacted mainly to issues that engaged Russian interests (Webber 2007, 270-73). One of these was the proposed missile shield.

American security interests also incorporate a view of Central Europe as a buffer against hostile regimes and terrorist groups that emanate from the east. The 2002 NATO summit approved the Prague Capabilities Commitment, which focused in part on creation of a common barrier against a potential threat from chemical, biological, radiological, and nuclear threats. The summit participants also agreed on four categories of action to counteract future terrorist acts and laid plans to create a Terrorist Threat Intelligence Unit (Terzuolo 2006, 107-10). Changes in intelligence procedures included common projects in four distinct areas: firmer airline security, barriers against terrorist funding, border controls, and exchange of intelligence itself (Rees 2004. 178-79). Of course, the Central European nations would share in those projects, and the missile shield proposal would contribute to creation of the needed buffer.

In the end, Iran came to be a central feature in the arguments that American leaders used to justify the missile shield project. President Bush estimated, in a speech at the National Defense University, that Iran might possess the ability to strike a number of European allies by 2015 (USA Today 2007a). Concerns about 
Russian reactions to the project were always on the table. Secretary Gates followed up the Bush speech with comments intended to allay Russian fears, indicating that, with the agreement of the Czech leadership, Russia might obtain an invitation to inspect the military sites that were part of the missile shield (iDNES 20071). Thus, the security plans of the United States included a vision of Central Europe as a key player in the double effort to fend off terrorism and to reassure Russia that its interests would not be sacrificed.

\section{Czech Security Goals in Relation to American Objectives}

Czech goals in defense policy meshed with American objectives in a number of important respects. Participation in the broad transatlantic partnership was beneficial to most nations on the European continent, particularly the Czechs. At critical points in the history of Czechoslovakia, particularly in 1918 and then again during the World War II era, America provided key assistance in development of the nation. Then, in 1999, membership in NATO also brought the two closer together and created in the Czech leadership a conviction that they should take the new alliance obligations seriously. Following the catastrophe of 9/11, Czechs perceived the common linkage with the American effort to combat the global, intensified terrorist threat.

Czechs understood that Europe as a whole shared certain values with the United States, such as democracy, building a framework of stability, and attention to nations in the developing world. Economic goals were also similar across the Atlantic partnership. Steady economic growth, low inflation, full employment, fostering a market economy, and development of the world market were high on that agenda. It is also true that these transatlantic partners had a similar view of emerging global threats. Combating the spread of terrorism and weapons of mass destruction was a top priority on the list of security concerns. Both containing regional conflicts and checking rogue states also entered into the common threat perceptions. Joint work to stabilize the Middle East was a major topic of concern. Finally, the historic transatlantic partnership had a value of its own that required protection and nurturing (Černíková 2008, 41-43).

American-European friendship also served the national interest of the Czech Republic. Even though the United States was not a European state, in some sense it was a European power. Yet it had never made claims to European territory, and when one European power threatened the rest, the United States had helped to contain its ambitions. The simple fact of the heavy U.S. economic and military involvement in 
Europe served as a deterrent to non-European powers which might have had designs on European interests or even territory. While many Europeans became alienated from the United States after the invasion of Iraq in 2003, there were risks attendant in excessive anti-Americanism. A reversion by the United States to isolationism would not be in the interests of Europe more broadly or more specifically of the Czech Republic (Joch 2007). Such observations reinforced Czech participation in NATO and Czech receptiveness to American initiatives such as the missile shield proposal.

Historical links in the twentieth century between the Czech Republic and the United States were important in knitting the two together on common twenty-first century projects. In 1918, President Woodrow Wilson had played an important role in the founding of the Czechoslovak state, and in 1938 the United States was unique in its unwillingness to recognize the Munich appeasement of the Hitler regime. During World War II, America was the most consistent supporter of Czechoslovak independence. Czech and Slovak attitudes were more complex, however, in the postwar period. Although there was a widespread perception that the West had sacrificed Czechoslovakia at the Yalta Conference in 1945, there was also a realization that the United States had made an unsuccessful effort to extend Marshall Plan aid to the country. Thus, the American request for Czech participation in the missile shield was rooted in deep historical connections. While Russian hostility to the proposed Czech radar site was an immense problem, it made sense for Czechs to cast their lot with the Americans rather than with those who had betrayed or occupied the country (Klaban 2007). Both former President Václav Havel and incumbent President Václav Klaus issued these kinds of historical reminders in demonstrating their general receptivity to the American proposal. In sum, historical connections made acceptance of the radar site a natural step rather than an unusual policy initiative with no precedent in the nation's experience.

With regard to the new NATO linkage and the emerging terrorist threats, some Czechs perceived the old link to the United States to be the best bet for the future. In fact, the sense of security for Czechs in the post-9/11 world was no greater than it had been during the Cold War. Although terrorists had not hit the Czech Republic yet, they tended to strike nations that underestimated regional insecurity and chose to live in a false state of security. The Czech nation was additionally unprepared to cope by itself with this threat due to its long-standing suspicion of the military. Occupation by Warsaw Pact forces after 1968 reinforced an ingrown skepticism in the early 1990s about permitting growth fo their own powerful military in postcommunist times. Thus, it would have been difficult for leading figures within the Czech Ministry of Defense to push for either a much more dynamic military force or a 
greatly increased military budget. For these reasons, it was necessary for the Czech Republic to rely in the near future on American leadership of the NATO alliance. The United States had demonstrated a willingness to take on responsibility in major crises, while the EU was only slowly developing as a security actor (Vondra 2006). The capabilities in support of the EU Common Foreign and Security Policy were not yet consequential. Therefore, there was a significant set of Czech leadership attitudes and conclusions that sought to build on the historic transatlantic partnership. From that point of view, participation in the radar site was a logical outgrowth of NATO membership, reliance on the tested senior partner of that alliance, and acute awareness of the potential impact of the emergent terrorist movements on Czech territory and its population.

\section{External/Internal Politics and the Radar Site Proposal}

In an ideal world the intersection of American and Czech security goals would be unaffected by old-fashioned politics. In fact, both global and domestic political pressures have impinged on the policy process. Russian reactions to the proposal constitute the key international political pressure. Even though the new system would be directed against rogue states such as Iran and perhaps North Korea, the Russian leadership interpreted it as potentially useable against their nation. Thus, they raised many objections both to the U.S. proposal as well as to Polish and Czech receptivity to it. Domestic pressures also flowed from contrasting strands of Czech political parties. The Czech and Moravian Communist Party (KSČM), seeking to stem declining public support, hopped on the bandwagon of opposition to the radar site. In general, it had opposed the decision to join NATO in the first place, holding to its traditional Cold War suspicion of American intentions, and saw this new venture as reaffirmation of the original reasons for its hostility to American foreign policy. The Social Democratic Party (CSSD) was opposed to the plan as well. It was the opposition in the legislature and saw this issue as one it could utilize in the upcoming political campaign to dislodge the Civic Democratic Party (ODS) from power. In addition, it was a force on the left that included many who were skeptical of political leaders willing to yield too much to the Americans. Public opinion polls taken throughout the period of consideration of the plan typically showed a strong majority against it. In addition, protests in the area around Brdo, the radar site, occurred on a number of occasions. On the other hand, the ODS was the most 
consistent supporter of the proposal. A key question would be how successful the coalition leadership would be in navigating through these tricky political waters.

\section{The Russians}

Russian opposition was forceful and frequent. One observer noted that Russia had recently been flexing its military muscle in an effort to restore its great power status. Part of that effort entailed a public relations campaign for a renewed emphasis on the nuclear component of national security. This campaign became a more immediate priority after Russian leaders observed the role nuclear weapons played in the U.S. decision to invade Iraq in 2003. Instability in nations on its border that were close to potential nuclear powers in the Middle East reinforced the logic of enhancing its nuclear strength (Baev 2008, 83-85). For example, the 2003 Rose Revolution in Georgia and the 2005 Tulip Revolution in Kyrgyzstan certainly shocked Russia and made it more aware of the soft conditions in the buffer between its own territory and the more troublesome nations further south. The 2004 Orange Revolution in Ukraine touched the same nerves but involved a geopolitical location further from that center of trouble but closer to Central Europe. This overall perspective about both the direction of Russian foreign policy and the link between its nuclear priority and the search for international greatness offers a useful backdrop to consideration of its responses to the radar site proposal. The American plan for a missile shield in Central Europe basically put a dagger in the heart of Russia's efforts to expand its global impact through reliance on its capabilities in the area of nuclear deterrence.

Russian reactions became part of Czech political calculations right away. Some in the Czech Republic were concerned that Russia might react by providing more assistance to Iran. On the one hand, a future scenario might be one in which Iran's growing regional power approximated that of Pakistan, India, and China. A potential, although less likely, prospect was an expanded Iran that included a break-away Shiite sector of Iraq. On the other hand, Russian persuasive powers might convince Iran to back down in its nuclear ambitions. This eventuality could lead to a situation in which Russia itself would gain diplomatic stature as a world power (Suja 2008) Neither the emergence of Iran as a regional power nor the rise of Russia in global political respect would benefit Czech security interests.

Other Czech analysts concluded that Russia overstated its own vulnerability and hence the threat posed by the missile shield. Those scholars doubted that Russia 
was trailing that badly in the global balance of power. Suchý (2007) presented data to support his contention that Russian fears were overstated (see Table 1).

Table 1. Comparison of Russian and American Strategic Power (2007)

\begin{tabular}{|l|r|r|}
\hline Category of Weapons & $\begin{array}{c}\text { Russia's Strategic } \\
\text { Power (2007) }\end{array}$ & $\begin{array}{c}\text { America's Strategic } \\
\text { Power (2007) }\end{array}$ \\
\hline ICBMs & 489 & 500 \\
\hline ICBM Warheads & 1788 & 1050 \\
\hline SLBMs & 173 & 336 \\
\hline SLBM Warheads & 609 & 2016 \\
\hline Strategic Bombers & 79 & 115 \\
\hline Bomber Warheads & 884 & 1955 \\
\hline
\end{tabular}

Although the United States maintained a lead of 951 to 741 in the total number of strategic weapons, and a lead of 5021 to 3281 in total warheads, Russia was a strong nuclear power. Its numerical capabilities certainly offered a degree of protection that undermined the credibility of its seemingly nervous concerns about the missile shield.

At one point in the debate, Putin made a proposal to locate the missile shield at the Gabala site in Azerbaijan, which would address the potential Iranian problem and could also increase Russian leverage on regional politics. Of course, this Putin proposal was predicated on the assumption that the Czech-Polish system would then no longer be necessary. In Suchý's estimation (2007), one result might be increased leverage by Azerbaijan over Russian policy. He averred that a Russian site such as Gabala should supplement rather than replace the American proposal for Central Europe. Again, he concluded that there was no pressing need to overestimate Russian pressure or to react to each of its provocative statements.

In light of increased tension on the issue, American and Russian leaders developed initiatives to defuse the situation. In May 2007, America and Russia agreed to hold a joint meeting of their defense and foreign ministers (iDNES 2007a). One month later Russian Minister of Foreign Affairs Sergei Lavrov suggested that the NATO-Russia Council was the best vehicle for discussion of the issues that divided the two. The proximity of the proposed site to the Russian border was the factor that activated Russian concern at that time. Lavrov contended that it was natural for Russia to apply pressure against that extension of American influence into Central Europe (iDNES 2007d). Russia may also have feared that its own radar defense 
capabilities would not match the ones proposed for Poland and the Czech Republic. In fact, later in the summer of 2007, Russia apparently dismantled two aging, Cold War radar stations in Ukraine (sme 2007a). On the anniversary of the Warsaw Pact invasion of Czechoslovakia in 1968, the chief of the Russian Army, Jurij Balujevskij, called upon the Czechs to postpone their decision about the missile site until after the American elections at the end of 2008. Ironically, even American politics were entering the discussion about the Brdo site. The Russian commander also threatened to aim Russian ballistic missiles at points in the Czech Republic, if the radar site plans materialized (iDNES 2007g). It was obviously very difficult to keep tension out of any discussions about these sites.

The American side also sent up some trial balloons. In late October 2007, Defense Secretary Robert Gates seemed to be considering the possibility of constructing the sites but delaying their "activation" until Iran made its missiles a more definitive threat. Simultaneously, he presented a plan to Russia to permit them physical access to the bases, although Czech willingness to accept the presence again of Russian troops on its soil was problematic (USA Today 2007b). However, Moscow rejected that concession as unacceptable; Czech Defense Minister Vlasta Parkanová was skeptical as she recalled serving on the parliamentary commission that oversaw the departure of Soviet troops after 1989; and a U.S. Defense Department spokesperson backed off from Gates's earlier comments to say that they had only constituted thoughts rather than a concrete proposal (iDNES 2007m). In fact, Russia escalated the rhetoric one month later by including Belarus in retaliatory plans. For some time, Belarus had desired to strengthen its army with the Russian Iskander rocket (iDNES 2007q). Nearly a year later, Belarus again entered the dialogue by making an agreement with Russia for a joint space defense system as a reaction against agreements signed by NATO states. This agreement would build on the union that they formed earlier in 1997 (sme 2008b).

At the end of the year, Russia decided to retaliate in another way, by pulling out of the 1990 Conventional Forces Agreement/Europe. The status of that agreement was somewhat unusual, for Russia had updated it in 1999 to take account of the break-up of the Soviet Union. However, Russia was the only country that signed the 1999 modification. All NATO nations refused to sign, because they disagreed with the continued presence of Russian soldiers in both Moldova and Georgia. Prior to President Putin's announcement of the withdrawal from the agreement, both chambers of the Russian legislature had called for such a move. They justified abrogation of that agreement through references to American plans to build the missile shield (sme 2007b). 
In early 2008, Czech Prime Minister Mirek Topolánek continued to work on plans with the American government with an eye to signing the radar agreement sometime in the middle of the year. President Putin continued to protest that emplacement of such a system so close to the Russian border would destabilize the European balance of power, comparing the project to the Cuban Missile Crisis in reverse (iDNES 2008b). In the spring of the year, the matter of a physical Russian presence at the base surfaced again as an issue. Minister of Defense Lavrov complained that the written agreement seemed to be at odds with the verbal promises made by the Americans. He had heard talk of a permanent Russian presence on the sites, but the written agreement outlined a situation in which Russians would be located at their embassies in Prague and Warsaw, having the right to visit the bases on occasion (iDNES 2008g). American willingness to permit a Russian presence of any sort was based on realization of Moscow's acute sensitivities regarding the whole project.

Russian signals continued to be mixed in the fall of 2008, even after the Americans had signed the agreements with the Czechs and Poles. On the one hand, Nikolaj Solovsov, commander of Russian rocket forces, seemed somewhat calmer about the proposed missile shield. He said that he was reconciled to the existing program, as long as no expansion of it occurred. He acknowledged the force of the argument that the proposed system could not really threaten hundreds of Russian rockets with multiple warheads. At the same time, he could not help but point out that there was still the possibility of aiming Russian rockets at Poland and the Czech Republic (iDNES 2008p). On the other hand, Dmitrij Rogozin, Russian ambassador to NATO, spoke in more ominous tones. In his view, the Czechs were sacrificing the security of their people to western demands. There was no difference between defensive and offensive weapons, and Russia needed to assume the worst when it confronted strengthened defenses in suspect countries (iDNES 2008r). In the midst of this discussion, Russia tested a new guided missile called Bulava, designed to evade the type of missile shield being planned for Central Europe (dagensnyheter 2008). This test served as a reminder of Russian capabilities. When rumors about Russian soldiers in the area around Brdo surfaced at about the same time, more suspicions on both sides were fueled (iDNES 2008u).

Clearly, there was no way of predicting or guessing what the Russian reactions would be on a given day. Their attitudes over time combined bold posturing, anxious defensiveness, and rational argument. In all situations they remained a potent factor influencing both the dialogue and the decision-making process. 


\section{Czech Party Politics}

Domestic politics in the Czech Republic also influenced the conversation. With control of the government, the ODS took the lead in support of the missile shield. Prime Minister Topolánek, who strongly favored the new system, sometimes spoke in dramatic terms, suggesting that inattention to a country's defense could result in a threat to civilization. In his view, Europe slumbered into a rosy dream after the end of the Cold War. He could not comprehend how the events of 9/11 and the Madrid bombings did not awaken the Europeans from that slumber (iDNES 2007b). At the same time, he held firmly to the belief that America should bear the entire cost of the project. He also expressed concern for popular anxiety that the radar itself might jeopardize public health (iDNES 2007c). President Václav Klaus also offered his thoughts about the agreement on occasion. In the summer of 2007, he said he would consider such opposition proposals as the call for a referendum on the matter. However, he simultaneously warned against the danger of stirring up "cheap populism" through referendum campaigns (IDNES 2007e). One issue that opposition leaders continually brought up was the possibility of linking the new facility to NATO rather than to the United States. Karel Schwarzenberg, minister of foreign affairs, agreed that the facility should be incorporated into NATO, although the Americans should still possess control over usage of the system. In particular, his speech stirred up the Green Party, part of the government coalition, which saw him as departing too much from the Green platform (iDNES 2007k).

Czech politicians became quite animated when American intelligence concluded that Iran had stopped work on its nuclear facilities in 2003. Opposition leader Jiř́ Paroubek immediately called for termination of the radar site proposal (iDNES 2007r). A few months later he wrote to the prime minister, asking him to cancel his trip to the United States and any plans to sign the agreement. He also questioned whether the radar site would strengthen or weaken Czech security. Might the plans worsen Czech relations with other European countries? In his view, the Czech nation needed to have the right to vote on the radar site via a referendum (iDNES 2008a). Prior to Polish acceptance of the American plans for them, there was a minor debate in the Czech Republic over the meaning of possible Polish rejection of the ten interceptors. Minister of Defense Vlasta Parkanová quickly suggested that Polish rejection would send plans back to the drawing board. Prime Minister Topolánek thought that her statement was courageous but premature. A spokesman for the minister of foreign affairs countered that the radar system by itself would 
strengthen Czech security (iDNES 2008c). Czechs should not be concerned about what the Poles were doing.

Former president Václav Havel brought another factor to the discussion table, one that supported the American initiative. He took the long historical perspective by observing that the Americans had supported Czechs in the founding of their state in 1918, during World War II, and then at the time of the fall of the Iron Curtain. For the first time America was asking something of them, and the nation had an opportunity to repay its obligation. He compared the pacifists who opposed the project to those who called for doing nothing against Hitler prior to the Munich Agreement of 1938 (iDNES 2008d).

One additional political issue to appear was linking the signing of the radar site accord with ratification of the EU's Lisbon Treaty that replaced the failed effort to establish an EU constitution. Opposition political leaders threatened to take the radar agreement to the Constitutional Court for a ruling on its legality. If that happened, key ODS members of the senate threatened to take the Lisbon Treaty to the courts for consideration. Thus, there was an attempt by the government to make the Lisbon Treaty a hostage of the decision on the radar base. In fact, it was the Communists who had the most interest in taking the radar agreement to the courts. Without the support of the Social Democrats, however, they would not have had enough legislative votes to meet the threshold required for submission to the court (iDNES 2008h).

As the prospect of elections loomed upon the horizon in 2009, party platforms became a more significant factor. The election program of the ČSSD stated that deployment of the radar site should depend on the approval of a majority of the citizens, most probably in a referendum (ceskastranasocialnidemokracie 2009). The KSČM was much more scathing in its official statements. Even after the inauguration of President Obama, its leaders continued to point to citizen opposition and to the fact that the system was virtually untested. They also argued that the huge investment in the shield made no sense at a time of economic crisis. In their view, American lobbying interests and the military-industrial complex were driving the new policy (komunistickastranacechamoravy 2009).

Thus, all the key political forces had an opinion about how to handle this controversial issue, and there was no possibility of reconciling them. However, the range of issues demonstrates how extensive the discussion continues to be and can be considered as a positive step in terms of the maturation of Czech democracy. 


\section{The Public}

Public opinion polls in the Czech Republic played a significant role in the political process. As early as December 2006, one key poll (Ivan Gabal Analysis $\&$ Consulting) revealed that a majority of Czechs favored the system if it included only the radar component. However, if missiles were connected with the radar, then a majority opposed approval or construction. The poll also revealed that those who supported NATO in general were more approving of the radar site than those with little trust in the alliance. In addition, support and opposition to a referendum about the site was about equal. In general, Czechs did see nuclear activity by Iran and North Korea as dangerous, but mostly they preferred economic and diplomatic pressure to military solutions (iDNES 2006b). By the middle of 2007, however, public opposition to the project had grown. The Center for Research on Public Opinion did a public opinion poll that revealed that two-thirds of Czech respondents were in opposition by that time, and the opponents were beginning to advocate the referendum as a logical next step in the discussion. Perhaps another expression of public opinion was a study done by Czech experts with information provided by the Americans. They concluded that the base would not endanger the health of persons living near the site (iDNES 2007f). The impact of such a study on the population was uncertain.

Occasional protests at the proposed site expressed the views of another segment of the public. In September 2007, protestors carried out demonstrations in fourteen villages near Brdo. The plan was to send five representatives to each village to talk with citizens and distribute leaflets. They were also going to present a document to a meeting at which the leader of the Communists, Vojtĕch Filip, would attend (iDNES 2007h). Iniciativa NE Základnám was one Czech group that had overwhelmingly opposed the new base. However, they dismissed the planned protest as the work of only the communists (iDNES 2007i). Another group, the Humanist Party, called for a boycott of American goods, in the tradition of Gandhi and Martin Luther King. Its leader, Jan Tamáš, called for a series of concerts, festivals, and meetings with prominent personalities in order to magnify the opposition (iDNES 2007t).

By the spring of 2008, the protests had increased in size; in May, several hundred people demonstrated in Prague. Iniciativa NE Základnám organized protests and also supported Greenpeace in its week-long, continuing, resistance activities at Brdo. About the same time, SC \& C, the Market Research Directory, did another public opinion survey that reinforced the conclusion that a majority of Czechs opposed the base. That survey discovered that the typical supporter of the base was 
a male with a high-school education who lived in a city of more than one hundred thousand inhabitants. In contrast, the typical opponent was a woman over sixty years of age with only a lower-school education (iDNES 2008i).

Protests continued even into July 2008, the month of the signing ceremony and the visit by Secretary Rice. Iniciativa NE Základnám set up a tent on Wenceslaus Square and planned at least one demonstration. Visitors to their tent would be able to vote in a virtual referendum on the radar plan. Greenpeace was also planning to organize a demonstration (iDNES 2008j). Some wondered if threatening events might throw public opinion back toward support for the base. However, there was no evidence of that. CVVM did a survey of opinion one month after the Russian invasion of Georgia. Still, opposition to the base by Czech citizens amounted to 67 percent. It was expected that the debate would continue on this controversial proposal iDNES 2008w).

\section{At Last, the Signing Ceremony}

A number of NATO summit meetings of heads of state had devoted some discussion to the proposed missile shield. The Prague summit in 2002 listed such a project of antimissile defense as one of its main priorities (iDNES 2006a). In November 2006, the leaders had put the missile shield proposal on their agenda at their Riga summit and decided to give further study to its feasibility. In the fall of 2007, NATO Secretary General Jaap de Hoop Scheffer gave higher priority to the project, saying that the antimissile system would be one of the main themes at the Bucharest summit in April 2008 (iDNES 2007p). At that summit Foreign Minister Schwarzenberg announced both that the Czechs had accepted the American proposal and that they were planning the official signing ceremony. Alliance leaders noted further that they supported the project and expected that in the future it would actually become a NATO system. Official NATO support was a surprising summit result for the Czechs. However, some issues were still unresolved. One was the Status of Forces Agreement (SOFA), which pertained to the movement of American soldiers on Czech soil. Another was a tougher upcoming discussion about controls over Russian officers and experts in the area of the radar base (iDNES 2008e).

Planning for the signing ceremony intensified soon after conclusion of the Bucharest summit. Initial plans involved an invitation to Secretary of State Condoleezza Rice for a May signing, but the ceremony was later moved to July. At the time of these preparations, the political landscape and political party divisions were 
clear. Public opinion polls still showed that a majority of Czechs opposed the plans. Both the Social Democrats and the Communists were opposed and demanded a referendum. Within the governing coalition, the ODS led the support for the radar base. Part of the Green coalition partner was supportive, and part was opposed. The Lidovci, the other coalition party, was still registering misgivings about the new plans (iDNES 2008f).

There was a minor setback for the project between the Bucharest summit in April and the official signing ceremony in July. At their summit in Slovenia, leaders of the EU nations considered the question of support for the missile shield. In the end, they decided that it was a NATO project and did not fall within their jurisdiction (sme 2008a).

In early July, the signing ceremony finally took place, and Secretary Rice traveled to Prague for the occasion. Despite the ceremony, many unfinished issues lingered in the atmosphere. The Poles had not yet signed their agreement to accept the ten antimissile interceptors. The SOFA document on movement of American troops was not yet ready, and plans for inspections by Russian troops were not close to being in final form. Also, the parliamentary vote had not yet been scheduled (iDNES 2008k). Nevertheless, Prime Minister Topolánek was forceful in defending the project. He did not see the threat of ballistic missiles as an imaginary one, and he warned his countrymen and countrywomen not to repeat the earlier Czechoslovak failure to accept Marshall Plan aid after World War II (iDNES 2008n). Schwarzenberg pointed out that the missile shield would protect not only the Czech Republic but also Europe and the whole Euroatlantic sector (iDNES 2008m). President Klaus, recovering from surgery, expressed no doubts and stated that he would sign the agreement, after the legislature approved it. In his view, the Czech Republic needed to stand on two legs, one American and one European (iDNES 20080).

Another piece of the puzzle fell into place in September, when the Czech minister of defense and the American secretary of defense finally signed the SOFA. One important condition of the agreement permitting American soldiers to operate on the base was that the land and physical property would remain in Czech hands. Czechs would be responsible for security outside the station and the Americans for security within it. That signing ceremony was planned for September 19, at a meeting of NATO ministers of defense in London. Robert Gates and Vlasta Parkanová were the persons who ended up signing that document (iDNES 2008q). On the American side, the defense bill that President Bush had sent to Congress at that time included $\$ 466$ million to develop the missile shield system in both Poland and the Czech Republic (CQ Today 2008). One important footnote to these negotiations was an additional 
agreement that treated the process of actually building the base. The Czech prime minister proposed to the cabinet an agreement that accorded Czech industry a primary role in construction of the facility. Czechs would also benefit from participation in the research and development of the components of the site and would learn from the exchange of specialists between the two countries (iDNES 2008v).

These additional agreements made the details of the project much more concrete. It would remain to be seen if they would firm up the opposition to or the support for the base. Much would depend on media interpretation and the positions taken by the various political party leaders.

\section{Changes during the Obama Administration}

In March 2009, after the inauguration of Barack Obama as U.S. president, there was a flurry of discussion about possible new directions with regard to the missile site. During the lengthy and strenuous election campaign, Obama gave the impression that he was less committed to the project than President Bush. In early March, he sent a letter to President Dmitry Medvedev of Russia with the hint of a compromise. He requested assistance from Russia in solving the touchy issue of Iran's nuclear program. In exchange for such assistance, he suggested that he would be willing to consider canceling the missile shield in the Czech Republic and Poland. Reference to this letter appeared in the Russian newspaper Kommersant, the source unnamed. Officially, the new U.S. administration had not yet spoken about this offer, and Czech Prime Minister Topolánek said that he had no information that the Americans had made a decision on the matter (iDNES 2009a). A day later the media fleshed out the story further in stating that an American diplomat had delivered the letter to the Russian president three weeks earlier (dagensnyheter 2009a).

Several weeks later President Medvedev made news with a surprise of his own. In 2011, Russia would begin more vigorous rearmament of its ground and naval forces. The factors that pushed them in this direction were the spread of global terrorism and the advance of NATO to Russia's doorstep. Another change in strategy would be the focus on purchasing totally new equipment. Since the end of the Cold War, he lamented, Russia had relied too much on repair of its older equipment. He did acknowledge that President Putin had made some improvements in Russia's military strength, thanks to the oil-inspired economic boom of the early twenty-first century (iDNES 2009b). Thus, the signals were very mixed. Were the Russians 
responding to President Obama, if he indeed had dispatched the diplomat with the letter? Or, were the Americans and Russians once again talking past one another?

Then, in the fall of 2009, it was President Obama's turn to bring surprising news. He canceled the entire missile shield project and replaced it with a lowercost reliance on existing sea-based and land-based capabilities. The announcement to both Poles and Czechs came in the middle of the night of September 17, 2009 (iDNES 2009c). Intelligence reports from the Pentagon showed that Iran was no longer developing the type of long-range weapons against which the missile shield was designed (USA Today 2009b). Current expectations were that its focus was on short-range missiles (5,000 miles) that could threaten all of Europe. The new American plan would, however, still have components in Poland and the Czech Republic (USA Today 2009c). Technological problems had also been part of the calculus in making this change: five of thirteen tests of the missile had failed to hit targets, and planners had not figured out ways to overcome the problem of decoys (USA Today 2009a).

Czech and Polish reactions were mixed. On the one hand, ČSSD Chair Jiří Paroubek called the new decision a "victory for the Czech people." While those who were connected with the antiradar protest movement were genuinely enthusiastic, ODS leader Miroslav Topolánek warned about threats to the Czech Republic that would ensue after cancellation. A more circumspect President Klaus simply said that he was not surprised (iDNES 2009e). As for the potential increase in threats from Russia, he said that he feared the EU more than Russia (iDNES 2009g).

Polish leaders tended to be more apprehensive than their Czech counterparts about the uncertainty of Russian intentions. Would cancellation invite more aggressiveness by that historic enemy (IDNES 2009d)? President Lech Kaczynski worried publicly that Poland would now find itself in a precarious "gray zone" between Western Europe and former Soviet space (Washington Times 2009). In fact, the Poles did not talk to President Obama until the day after the Czechs did. Either Prime Minister Tusk refused to accept the call, or phone communications broke down.

Certain Polish neighbors had a stake in the debate as well. For example, Lithuania shares a border not only with Poland but also with the Russian enclave of Kaliningrad, which is totally surrounded by Polish and Lithuanian territory. Given Russian rhetorical gestures about locating Iskander missiles in Kaliningrad in retaliation to the missile shield proposal, Lithuanian's vulnerability led its leaders to support the Bush plan. Thus, it is no surprise that their reactions to the cancellation were similar to those of the Poles. The Lithuanian foreign minister described Obama's announcement as "not the best news" (Izvestiya 2009a). 
Russia's reactions were not mixed. President Medvedev called Obama's decision a "responsible" one, and he was prepared to continue dialogue with the United States on a variety of issues (iDNES 2009f). Prime Minister Putin expressed the hope that the United States might be willing to open the door to Russian membership in the World Trade Organization (dagensnyheter 2009c). One positive step by Russia pertained to the Kaliningrad issue. Deputy Defense Minister Vladimir Popovkin stated that deployment of the Iskander short-range missiles to Kaliningrad was now unnecessary (USA Today 2009d). In fact, Russia's earlier concerns that the shield might be directed against them as well as Iran may have had some basis in fact. Secretary of Defense Robert Gates spoke with reporters after a formal presentation at the Air Force Association convention. In those comments, he mentioned that the proposed Czech radar site could have monitored Russian ICBM activity as well as work in Iran. Previously, Pentagon officials had denied that the system had the potential to see as far as the Caucasus Mountains (Washington Post 2009).

AT NATO headquarters, the new secretary general, Anders Fogh Rasmussen, attempted to put the new situation into a broader, alliance-based framework. He asserted that there might be a future proposal that would link the United States, NATO, and Russia into a missile shield program. He compared such future cooperation to the links among all three in the global battle against terrorism (sueddeutsche 2009). Hans Blix from Sweden, the former U.N. chief for nuclear arms inspections, greeted the Obama decision with the words, "It was high time." He also contended that Russia would now feel a greater sense of security and could more confidently take part in arms control talks. Blix also welcomed Obama's intention to engage in discussions with Iran (dagensnyheter 2009b).

Within a few weeks, the outlines of President Obama's replacement plan became public. Reliance would be principally on the navy's SM-3 interceptor missiles. The initial cost would be $\$ 10,000,000$ per missile in contrast to the previously planned missile shield interceptors that would have required $\$ 70,000,000$ per missile. In late September 2009, the existing SM-3 missiles were carried on eighteen Aegis cruisers. Incorporation of them into the new program would require that three of those cruisers, each with one hundred SM-3s, would be on continuing patrol in the Mediterranean and North Sea by 2011. The land-based counterparts of this system would be erected between 2015 and 2020, and their primary benefit would be considerable expansion of the territory that the interceptor missiles could defend (USA Today 2009e). Confirmation that those new land-based interceptors would also be located in Poland came quickly (sme 2009). 
Official, high-level conversations about the new plan took place during Vice President Joseph Biden's visit to Poland, Romania, and the Czech Republic, October 20-24, 2009. In Poland, he discussed the possibility of introducing the SM-3 missiles after 2015, and Polish leaders were receptive. Prime Minster Donald Tusk labeled the new project interesting and indicated that his country would take part in it. Clearly, the government had rebounded from its disappointment during the surprise of the previous month. Biden assured the Poles that the new project would be more effective than the previous one (Izvestiya 2009b). Czechs were prepared also to accept their prospective role as the site of the command post for the new system, although the nature of that role was uncertain at the time of the visit. Prior to the Biden trip, Under Secretary of State Ellen Tauscher had described how a command system for development and control of the components of the new system would be put in the Czech Republic (iDNES 2009h). However, the description changed somewhat during the Biden visit. Prime Minister Jan Fischer made a more general reference to Czech willingness to participate in a new architecture, and the specifics included creation of an office in the Czech Republic. In that office, presumably, Czechs and Americans would work together on the scientific and research aspects of the new system (iDNES 2009i). Future discussions would clarify the exact nature of this collaboration.

\section{Conclusion}

Plans for increasing the military security of Europe may have shifted away from the Bush administration's missile shield project, but security threats did not abate in the ensuing months. Iran, the main target of the canceled project, continued to engage in a cat-and-mouse game over its nuclear intentions. At times, the Iranian leadership leaned toward cooperation with EU initiatives that set up a network of nations to process Iran's nuclear fuel to make certain that its uses would be for peaceful purposes. At other times, they transformed nuclear discussions with the West into a political quagmire that always centered on claims of Iranian sovereignty. It was difficult for the nations of Europe to settle into any sort of security comfort zone.

Moreover, events further east continued to be very unsettling, even as the Iraq War was winding down. De-escalation of violence in Iraq was accompanied by a sharp increase in militant attacks in Afghanistan. European leaders and publics felt continued pressure to respond to American initiatives for an Afghan parallel to the successful surge strategy of General Petraeus in Iraq. The Obama administration 
called for an additional 21,000 troops in spring 2009, and the president committed another 30,000 troops in November of that year. Requests for additional troops from the NATO allies were issued at the same time. Such expectations of the NATO partners were not just based on concerns about adequate contributions from them; they were also rooted in the realization that Europe's psychological and emotional security depended as well on reduction of the power of the Taliban and al Qaeda immediately across the continent's eastern frontier. This was particularly so because of the fear that terrorist groups might obtain their own nuclear capabilities through the assistance of tacitly supportive leaders in nearby states. In fact, this fear led to scheduling a multinational conference on such a threat in Washington in spring 2010.

Intensification of the violence in Pakistan, especially in its Federally Administered Tribal Areas, compounded the worries and uncertainty in Europe. It was much more difficult for NATO to engage in forays into Pakistan, and the alliance needed to depend on use of drones in combination with the willingness and ability of a weakened Pakistani government to have any effect at all.

All this turbulence drove home the need for new and effective plans that would ensure regional security and also be acceptable to Europeans. One such plan was the Russian-American Strategic Arms Reduction Treaty that would reduce sharply both the number of missiles and the number of warheads on both sides. Symbolically, both presidents met at the Prague Castle on April 8, 2010, to sign the treaty. In midMay, Obama called Medvedev with the news that he had submitted that treaty to the Senate for consideration. Both chambers of the Russian parliament would also consider the agreement in the near future (2010). In the end, there was no luxury of time in the aftermath of the missile shield cancellation. Hesitation would prove costly and the security of Europe would be thereby diminished. 


\section{References}

Argentieri, Federigo. 2008. "Hungary: Dealing with the Past and Moving into the Present." In Central and East European Politics: From Communism to Democracy, ed. Sharon L. Wolchik and Jane L. Curry, 215-232. New York: Rowman \& Littlefield.

Baev, Pavel. 2008. Russian Energy Policy and Military Power: Putin's Quest for Greatness. New York: Routledge.

Baskin, Mark, and Paula Pickering. 2008. "Former Yugoslavia and Its Successors.” In Central and East European Politics: From Communism to Democracy, ed. Sharon L. Wolchik and Jane L. Curry, 281-316 New York: Rowman \& Littlefield.

Černíková, Petra. 2008. “Evropská unie a Spojené státy americké: Politické vztahy na počátku 21st století." Mezinárodní Politika 32, no. 1: 41-43.

Ceskastranasocialnidemokracie. 2009. "Volební program.” March 17. http://www.kscm.cz (accessed March 17, 2009).

CQ Today. 2008. "Defense policy bill nearly ready for Bush." September 24, 2008. daniel. meyer@dodigmil (accessed on September 24, 2008).

dagensnyheter.se. 2008. "Ryssland testar ny robot." September 18. http://www.dagensnyheter.se (accessed September 18, 2008).

dagensnyheter.se. 2009a. "Obama sőker ryskt stőd för att stoppa Irans missiler.” March 4. http://www.dagensnyheter.se (accessed March 4, 2009).

. 2009b. "USA skrotar robotplaner." September 17. http://www.dagensnyheter.se (accessed September 17, 2009).

_. 2009c. "Putin vill ha mer efter missilbeslut." September 18. http://www.dagensnyheter. se (accessed September 18, 2009).

Eglitis, Daina Stukuls. 2008. "The Baltic States: Remembering the Past, Building the Future." In Central and East European Politics: From Communism to Democracy, ed. Sharon L. Wolchik and Jane L. Curry, 233-252. New York: Roman \& Littlefield.

Garwin, Richard L. 2008. "Evaluating Iran's Missile Threat.” Bulletin of the Atomic Scientists, May/June, 40-44.

Gledhill, John, and Charles King. 2008. "Romania Since 1989: Living Beyond the Past.” In Central and East European Politics: From Communism to Democracy, ed. Sharon L. Wolchik and Jane L. Curry, 317-338. New York: Rowman \& Littlefield. 
Hesli, Vicki L. 2007. Governments and Politics in Russia and the Post-Soviet Region. New York: Houghton Mifflin.

iDNES. 2006a. "NATO začalo budovat protiraketovou obranu." November 28. http://www.idnes.cz (accessed November 28, 2006).

. 2006b. "Výzkum: Češi by povolili americký radar, rakety nechtějí." December 15. http://www.idnes.cz (accessed December 15, 2006).

. 2007a. "USA a Rusko dohodly schůzku o raketách a radaru." May 4. www.idnes.cz (accessed May 4, 2007).

—. 2007b. “Topolánek: Pokud se Evropa nebude bránit, je s ní konec.” May 31. http://www.idnes.cz (accessed May 31, 2007).

___ 2007c. "Premiér: Radar odmítneme, pokud si ho USA nezaplatí." June 3. http://www.idnes.cz (accessed June 3, 2007).

—_— 2007d. "Rusko chce spojit svou obranu proti raketám s NATO." June 3. www.idnes.cz (accessed June 3, 2007).

___ 2007e. "Pozor na populismus, píše Klaus o referendu k radaru." July 13. http://www.idnes.cz (accessed July 13, 2007).

—_—_. 2007f. "Průzkum: Američané chtějí radar v Čechách." July 30. http://www.idnes.cz (accessed July 30, 2007).

—. 2007g. “České ‘ano’ radaru je chyba, zopakovalo Rusko.” August 21. www.idnes.cz (accessed August 21, 2007).

. 2007h. "Komunisté obsadí Brdy, zastánci radaru chystají protiakci." September 20. http://www.idnes.cz (accessed September 20, 2007).

—. 2007i. "Komunisté agitují v Brdech proti radaru.” September 21. http://www.idnes.cz (accessed September 21, 2007).

___ 2007j. "Šéf Pentagonu přiletěl do Česka jednat o radaru." September 22. http://www.idnes.cz (accessed September 22, 2007).

—. 2007k. "Schwarzenberg: Radar bude pod NATO, raketu odpálí USA." October 7. http://www.idnes.cz (accessed October 7, 2007).

—__ 20071. “Základny aktivuje až hrozba z Íránu, navrhl Gates.” October 23. http://www.idnes.cz (accessed October 23, 2007). 
2007 m. "Nový americký návrh k radaru Rusy neuspokojil.” October 25. http://www.idnes.cz (accessed October 25, 2007).

2007n. "Scheffer: Radarem se bude zabývat summit NATO." October 31. http://www.idnes.cz (accessed October 31, 2007).

. 2007o. "Scheffer: Radarem se bude zabývat summit NATO." October 31. http://www.idnes.cz (accessed October 31, 2007).

. 2007p. "Scheffer: Radarem se bude zabývat summit NATO." October 31. http://www.idnes.cz (accessed October 31, 2007).

___ . 2007q. "Ruský general pohrozil raketami v Bělorusku." November 14. http://www.idnes.cz (accessed November 14, 2007).

2007r. "Padl hlavní důvod pro radar, jednání přesto běží dál.” December 5. http://www.idnes.cz (accessed December 5, 2007).

. 2007s. "Ministr Schwarzenberg chce dohodu o radaru ještě v zimě." December 7. http://www.idnes.cz (accessed December 7, 2007).

. 2007t. “Nekupujte americké zboží, vyzývají humanist po vzoru Gándhiho.” December 10. http://www. idnes.cz (accessed December 10, 2007).

2008a. "Nejedete do USA podepsat radar? Ptá se Parouobek premiéra." January 30. http://www.idnes.cz (accessed January 30, 2008).

2008b. "Bush po schůzce s Topolánkem: Dohoda o radaru je blízko.” February 27. http://www.idnes.cz (accessed February 27, 2008).

. 2008c. “Topolánek: Prohlášení Parkanové o radaru je předčasné.” March 10. http://www.idnes.cz (accessed March 10, 2008).

. 2008d. "Exprezident Havel: Američanům umístění radaru dlužíme.” March 24. http://www.idnes.cz (accessed March 24, 2008).

—. 2008e. “Česko se dohodlo s USA na radaru, smlouvu podepiše za měsíc.” April 3. http://www.idnes.cz (accessed April 3, 2008).

2008f. "Smlouva o radaru podepiše v Praze Riceová, zřejmě začátkem května." April 7. http://www.idnes.cz (accessed April 7, 2008).

2008g. "Rusko znovu apelovalo na přítomnost svých vojáků u českého radaru." April 8. http://www.idnes.cz. (accessed April 8, 2008). 
2008h. “Opozice hrozí kvůli smlouvě o radaru Ústavním soudem.” April 15. http://www.idnes.cz (accessed April 15, 2008).

2008i. "V Praze protestovaly proti radaru stovky lidí.” May 5. http://www.idnes.cz (accessed May 5, 2008).

2008j. “Odpo̊rci radaru budou Riceové spílat k večeři.” July 7. http://www.idnes.cz (accessed July 7, 2008).

. 2008k. "Schwarzenberg: Rakety u nás v případě polského odmítnutí neskončí.” July 7. http://www.idnes.cz (accessed July 7, 2008).

20081. “Česko a USA podepsaly hlavní smlouvu o radaru.” July 8. http://www.idnes.cz (accessed July 8, 2008).

2008m. “Česko a USA podepsaly hlavní smlouvu o radaru.” July 8. http://www.idnes.cz (accessed July 8, 2008).

. 2008n. "Nesmíme opakovat selhání z minulosti, hájl Topolánek radar.” July 8. http://www.idnes.cz (accessed July 8, 2008).

—. 2008o. "Klaus: Smlouvu o radaru podepíšu bez váhání.” July 9. http://www.idnes.cz (accessed July 9, 2008).

—. 2008p. "S radarem se můžeme smířit, nebo na něj zamířit, pravil ruský general." September 10. http://www.idnes.cz (accessed September 10, 2008).

- 2008q. "Vláda schválila smlouvu SOFA, radar I půda pod ním zůstane Česku." September 10. http://www.idnes.cz (accessed September 10, 2008).

. 2008r. “Ruský velvyslanec: Česká vláda prodala bezpečnost lidí za radar.” September 19. http://www.idnes.cz (accessed September 19, 2008).

—. 2008s. “Letadlo s tělem velvyslance Žd'arka miř́i z Pakistánu do Prahy.” September 22. http://www.idnes.cz (accessed September 22, 2008).

—. 2008t. "Raketovy útok v Afghánistánu zranil tři české vojáky.” September 22. http://www.idnes.cz (accessed September 22, 2008).

. 2008u. "Vojáci o ruském zájmu o půdu v Brdech mlčí, varují před agenty l̂́ránu I Kosova." September 29. http://www.idnes.cz (accessed September 29, 2008).

. 2008v. "Vláda schválila dohodu o zapojení Česka do budování protiraketového štítu." October 1. http://www.idnes.cz (accessed October 1, 2008). 
2008w. "Ruský vpád do Gruzie podporu radaru nepřinesl, ukázal průzkum.” October 3. http://www.idnes.cz (accessed October 3, 2008).

2009a. “Obama žádá Rusko o pomoc s Íránem, obětoval by radar v Brdech.” March 2. http://www.idnes.cz (accessed March 2, 2009).

. 2009b. "Teror sílí a NATO se blíží, varoval Medveděv a ohlásil ruské přezbrojení." March 17. http://www.idnes.cz (accessed March 17, 2009).

. 2009c. "Fischer: Radar nebude, sdělil me 21 minut po půlnoci Obama." September 17. http://www.idnes.cz (accessed September 17, 2009).

—. 2009d. “O konci radaru debatuje se čtenáři iDNES.cz generál Jiř́i Šedivý.” September 17. http://www.idnes.cz (accessed September 17, 2009).

2009e. "P̌̌EHLEDNĚ: USA “zamázly" radar v Bredech, Češi litují i oslavují." September 17. http://www.idnes.cz (accessed September 17, 2009).

. 2009f. “Zrušení radaru v Česku je zodpovědné, chválí Rusové Obamu.” September 17. http://www.idnes.cz (accessed September 17, 2009).

—. 2009g. "Bojme se Ruska méně než EU, prohlásil prezident Klaus.” September 22. http://www.idnes.cz (accessed September 22, 2009).

—. 2009h. "V Česku by mohlo být velitelství nového protiraketového system.” October 8. http://www.idnes.cz (accessed October 8, 2009).

. 2009i. “Česko se na protiraketové obraně chce podílet, řekl Fischer Bidenovi.” October 23. http://www.idnes.cz (accessed October 23, 2009).

Izvestiya. 2009a. "Head of the Ministry of Foreign Affairs of Lithuania is displeased with the decision of the USA on the Missile Shield" (translated). September 18. http://www.izvestiya.ru (accessed September 18, 2009).

- 2009b. "Poland does not question participation in the new Missile Shield project of the USA" (translated). October 21. http://www.izvestiya.ru (accessed October 21, 2009).

- 2010. "Obama informed the leadership of the RF (Russian Federation) on the introduction of the SNV (Strategic Arms Reduction Treaty) to the Senate" (translated). May 13. http://www.izvestiya.ru (accessed May 13, 2010).

Jentleson, Bruce W. 2007. American Foreign Policy: The Dynamics of Choice in the Twenty-First Century. 3d ed. New York: W.W. Norton. 
Joch, Roman. 2007. “Je-a má být-česká zahraniční politika proamerická.” Mezinárodní Politika 31, no.2: $1-20$.

Klaban, Vladimír. 2007. “Americký radar, Evropská unie, Rusko a my.” Mezinárodní Politika 31, no. 10: 19-21.

komunistickastranacechamoravy. 2009. "KSČM proti základnám USA v ČR.” March 17. http://www.kscm.cz (accessed March 17, 2009).

Lewis, George N., and Theodore A. Postol. 2008. "Why Countermeasures Will Defeat National Missile Defense." Bulletin of the Atomic Scientists, May/June, 38-39.

Michta, Andrew A. 2006. The Limits of Alliance: The United States, NATO, and the EU in North and Central Europe. New York: Rowman \& Littlefield.

Ministry of Foreign Affairs of the Czech Republic. 2009. "Mapa předpokládného rozšíření system Protiraketové obrany.” March 17. http://www.mzv.cz (accessed March 17, 2009).

Rees, Wyn. 2004. "Emerging Security Challenges.” In Redefining Transatlantic Security Relations: The Challenge of Change, ed. Dieter Mahncke, Wyn Rees, and Wayne C. Thompson, 163-207. New York: Manchester University Press.

sme. 2007a. "Rusko zatvorí svoje radarové stanice na Ukrajine." July 12. http://www.sme.sk (accessed July 12, 2007).

_ 2007b. "NATO varuje Rusko, aby neodstúpilo od zmluvy od odzbrojení." November 30. http://www.sme.sk (accessed November 30, 2007).

—. 2008a. "Európska únie nepodporila raketový štít USA." June 10. http://www.sme.sk (accessed June 10, 2008).

— 2008b. "Rusko a Bielorusko chcú zjednotit’ protivzdušnú obranu. October 8. http://www.sme.sk (accessed October 8, 2008).

—_ 2009. "Rusko: Nový americký štít vzbudzuje viac otázok ako odpovedí.” October 9. http://www.sme.sk (accessed October 9, 2009).

Suchý, Petr. 2007. “Protiraketová obrana a ruská paranoia.” Mezinárodní Politika 31, no. 7: 4-6.

Suja, Miroslav. 2008. “Irán a základny—test unipolarity.” Mezinárodní Politika 32, no. 3:32-35.

Terzuolo, Eric. 2006. NATO and Weapons of Mass Destruction: Regional Alliance, Global Threats. New York: Routledge. 
USA Today. 2007a. "Bush: Missile defense need is 'urgent.”' October 23. http://www.usatoday.com (accessed October 23, 2007).

2007b. “U.S. might delay missile defense plan.” October 23. http://www.usatoday.com (accessed October 23, 2007).

. 2009a. "Obama scraps Bush missile defense plan.” September 17. http://www.usatoday.com (accessed September 17, 2009).

- 2009b. "Pentagon: Obama adjusting European missile shield." September 17. http://www.usatoday.com (accessed September 17, 2009).

_-_. 2009c. "Obama scraps Bush missile-defense plan." September 18. http://www.usatoday.com (accessed September 18, 2009).

__— 2009d. "Russia scraps plan for missiles near Poland." September 21. http://www.usatoday.com (accessed September 21, 2009).

- 2009e. "Missile Shield." September 30. http://www.usatoday.com (accessed September $30,2009)$.

Vondra, Alexandr. 2006. “Česká zahraniční politika: tři princepy, trojí směřování, a tři témata.” Mezinárodní Politika 30, no. 11: 16-19.

Washington Post. "What's the news? Just ask Secretary Gates." September 22, 2009.

Washington Times. "Poles, Czechs criticize U.S. missile shield 'betrayal.”" September 19, 2009.

Webber, Mark. 2007. "Russia and the European Security Governance Debate." In Russia and Europe in the Twenty-First Century: An Uneasy Partnership, ed. Jackie Gower and Graham Timmins, 267-288. New York: Anthem.

Wolchik, Sharon L., and Jane L. Curry. 2008. "Democracy, the Market, and the Return to Europe: From Communism to the European Union and NATO.” In Central and East European Politics: From Communism to Democracy, Eds. Sharon L. Wolchik and Jane L. Curry, 3-32. New York: Rowman \& Littlefield. 
Center for Russian \& East European Studies

University Center for International Studies

University of Pittsburgh

4400 W. W. Posvar Hall

230 South Boquet Street

Pittsburgh, Pennsylvania 15260

(412) 648-8716

www.ucis.pitt.edu/crees/cbpaper.html.

Ronald Linden, Bob Donnorummo, William Chase, Co-Editors

Eileen O’Malley, Managing Editor

Julie Tvaruzek, Editorial Assistant 